\title{
Faktor Risiko Kepatuhan Pengobatan pada Penderita Tb Paru BTA Positif
}

\author{
Rojali $^{1}$, Noviatuzzahrah ${ }^{2}$ \\ ${ }^{1,2}$ Jurusan Kesehatan Lingkungan, Politeknik Kesehatan Kemenkes Jakarta II, Indonesia \\ Email: rojalijaya@yahoo.com
}

\begin{abstract}
Risk Factors for Treatment Compliance in Patients with Tuberculosis SmearPositive Pulmonary. This study was to determine the factors that affect the compliance of treatment of tuberculosis patients smear-positive pulmonary in Community Health Centers Cipondoh, Tangerang, Banten, the year 2015-2016. This research design was "case-control". The population was all positive pulmonary tuberculosis patients who received treatment and recorded in the listing sheet of TB-01 of Cipondoh Community Health Centers. Total samples were 35 people which been meet the inclusion and exclusion criteria. The result showed treatment compliance description which was $80 \%$ of tuberculosis pulmonary patients obedient to medication. A predisposing factor was $74.3 \%$ for men; $82.9 \%$ new types of sufferers; $82.9 \%$ duration of treatment 6 months. The enabling factor was $37.1 \%$ of the distance to the Community Health Centers $1.26 \mathrm{~km}$. The reinforcing factor of $80 \%$ did not have supervisor taking medicine. Analysis of the correlation between predisposing factor and compliance of tuberculosis treatment of smearpositive pulmonary, there was no relationship for gender variable, patient type, duration of treatment, and distance of home to Community Health Centers. Analysis of the correlation between reinforcing factor with compliance of tuberculosis treatment of smear-positive obtained no relation for the variable status of supervisor taking medicine.
\end{abstract}

Keywords: Tuberculosis smear-positive pulmonary, Tuberculosis treatment compliance and supervisor taking medicine

\begin{abstract}
Abstrak: Faktor Risiko Kepatuhan Pengobatan pada Penderita Tb Paru BTA Positif. Tujuan penelitian ini adalah untuk mengetahui faktor-faktor yang berpengaruh terhadap kepatuhan pengobatan penderita tuberkulosis paru BTA positif di Puskesmas Cipondoh Tangerang Banten tahun 2015 - 2016. Penelitian ini dilakukan dengan desain "case control". Populasinya adalah semua penderita tuberkulosis paru BTA positif yang mendapat pengobatan dan tercatat di formulir TB-01 Puskesmas Cipondoh Tangerang Banten yang memenuhi kriteria inklusi dan eksklusi yaitu 35 orang. Jumlah sampel pada penelitian ini 35 orang. Hasil penelitian diperoleh gambaran kepatuhan pengobatan penderita tuberkulosis paru BTA positif yaitu $80 \%$ yang patuh dalam pengobatan. Faktor predisposing sebesar 74,3\% laki-laki; 82,9\% tipe penderita baru; 82,9\% lama pengobatan 6 bulan. Faktor enabling sebesar 37,1\% jarak tempat tinggal ke puskesmas 1,26 km. Faktor reinforcing sebesar $80 \%$ yang tidak memiliki PMO. Dari analisis hubungan antara faktor predisposing dengan kepatuhan pengobatan tuberkulosis paru BTA positif tidak terdapat hubungan untuk variabel jenis kelamin, tipe penderita, lama pengobatan, dan jarak rumah ke Puskesmas. Sedangkan analisis hubungan antara faktor reinforcing dengan kepatuhan pengobatan tuberkulosis paru BTA positif didapat tidak ada hubungan untuk variabel status PMO.
\end{abstract}

Kata kunci: TB Paru BTA Positif, Kepatuhan Pengobatan TB dan PMO

Rencana strategi pembangunan kesehatan periode 2015-2019 salah satu sasaran kinerja dalam pengendalian penyakit menular adalah menurunkan angka kesakitan dan kematian dengan angka keberhasilan pengobatan TB paru BTA positif (Success Rate) minimal $85 \%$. (Kemenkes RI, 2015).

Tuberkulosis (TB) merupakan salah satu penyakit infeksi menular yang disebabkan oleh bakteri Mycobacterium tuberculosis yang dapat menyerang berbagai organ terutama paru-paru.
Penyakit ini akan menimbulkan komplikasi bahkan kematian apabila tidak diobati atau pengobatannya tidak sampai tuntas. Bakteri Mycobacterium tuberculosis dapat menyebar dari orang ke orang melalui udara, ketika orang yang menderita TB paru batuk, bersin, meludah, mereka mendorong kuman TB ke udara kemudian terhirup oleh orang lain sehingga penyakit ini semakin rentan untuk lebih luas dan akan menjadi temuan kasus yang semakin meningkat apabila tidak dikendalikan (WHO, 
2016). Gejala utama adalah batuk selama 2 minggu atau lebih, batuk disertai dengan gejala tambahan yaitu dahak, dahak bercampur darah, sesak nafas, badan lemas, nafsu makan menurun, berat badan menurun, malaise, berkeringat malam hari tanpa kegiatan fisik, demam lebih dari 1 bulan (Kemenkes RI, 2013).

WHO (World Health Organization) mengatakan bahwa tuberkulosis (TB) merupakan salah satu dari 10 penyebab kematian di seluruh dunia. Pada tahun 2015 ditemukan sebanyak 10,4 juta orang jatuh sakit akibat TBC. Lebih dari 95\% kematian akibat TBC terjadi pada orang yang berpenghasilan rendah dan menengah di dunia. Terdapat enam negara dengan angka kesakitan akibat TBC yaitu India, Cina, Nigeria, Pakistan, Indonesia dan Afrika Selatan. (WHO, 2016). Indonesia sekarang berada pada ranking kelima negara dengan beban TB tertinggi di dunia. Estimasi prevalensi TB semua kasus adalah sebesar 660.000 dan estimasi insidensi berjumlah 430.000 kasus baru per tahun. Jumlah kematian akibat TB diperkirakan 61.000 kematian per tahunnya (Kemenkes RI, 2011).

Prevalensi penduduk Indonesia yang didiagnosis TB paru oleh tenaga kesehatan tahun 2013 adalah $0,4 \%$, tidak berbeda dengan tahun 2007. Terdapat lima provinsi dengan kasus TB tertinggi diantaranya Jawa Barat, Papua, DKI Jakarta, Gorontalo, Banten dan Papua Barat. Dari lima provinsi dengan TB paru tertinggi salah satunya adalah Banten dengan angka prevalensi berdasarkan diagnosis dan gejala yaitu $(0.4 \%)$, berdasarkan karakteristik penduduk, prevalensi TB paru cenderung meningkat dengan bertambahnya umur, pada pendidikan rendah, tidak bekerja (Kemenkes RI, 2013).

Sekitar $75 \%$ pasien TB adalah kelompok usia yang paling produktif secara ekonomis yaitu 15-50 tahun. Diperkirakan seorang pasien TB dewasa, akan kehilangan rata-rata waktu kerjanya 3 sampai 4 bulan. Hal ini berakibat pada kehilangan pendapatan tahunan rumah tangganya sekitar 20-30\%. Jika ia meninggal akibat TB, maka akan kehilangan pendapatannya sekitar 15 tahun. Selain merugikan secara ekonomis, TB juga memberikan dampak buruk lainnya secara sosial, seperti stigma bahkan dikucilkan oleh masyarakat (Kemenkes RI, 2014).

Upaya pengendalian TB di Indonesia sudah berlangsung sejak lama, sejak tahun 1995 Program nasional pengendalian TB Paru mulai menerapkan strategi jangka pendek dengan pengawasan langsung melalui penerapan DOTS (Directly Observed Treatment Short-course) secara bertahap melalui Puskesmas. Dan pada tahun 2000 strategi DOTS dilaksanakan secara nasional di seluruh sarana pelayanan kesehatan terutama Puskesmas yang diintegrasikan dalam upaya kesehatan dasar (Kemenkes RI, 2014).

Berdasakan data Riskesdas tahun 2010 terdapat $19,3 \%$ penderita TB Paru yang tidak patuh dalam minum obat. Kepatuhan merupakan hal yang sangat penting dalam perilaku hidup sehat. Kepatuhan minum obat anti tuberkulosis adalah mengonsumsi obat-obatan sesuai yang telah diserepkan dokter, hal ini juga dipengaruhi oleh lamanya waktu pengobatan yaitu 6-8 bulan. Akibatnya apabila penderita tidak teratur meminum obat atau putus berobat, justru akan menimbulkan resistensi atau kekebalan ganda kuman TB Paru terhadap obat anti tuberkulosis. Dan pada akhirnya biaya pengobatan yang dikeluarkan akan lebih tinggi, mahal serta waktu yang relatif lama (Prayogo, 2013).

Berdasakan data Riskesdas tahun 2010 terdapat $19,3 \%$ penderita TB Paru yang tidak patuh dalam minum obat. Kepatuhan merupakan hal yang sangat penting dalam perilaku hidup sehat. Kepatuhan minum obat anti tuberkulosis adalah mengonsumsi obat-obatan sesuai yang telah diresepkan dokter, hal ini juga dipengaruhi oleh lamanya waktu pengobatan yaitu 6-8 bulan. Akibatnya apabila penderita tidak teratur meminum obat atau putus berobat, justru akan menimbulkan resistensi atau kekebalan ganda kuman TB Paru terhadap obat anti tuberkulosis. Dan pada akhirnya biaya pengobatan yang dikeluarkan akan lebih tinggi, mahal serta waktu yang relatif lama (Prayogo, 2013).

Penelitian oleh Prayogo (2013) menyatakan bahwa jarak rumah menuju Puskesmas berpengaruh terhadap kepatuhan berobat penderita ke Puskesmas, semakin jauh jarak rumah kepala keluarga ke tempat pelayanan kesehatan semakin sedikit penggunaan pelayanan kesehatan.

Berdasarkan data Dinas Kesehatan Kota Tangerang, jumlah kasus Suspect TB Paru pada tahun 2015 sebanyak 7.455 kasus, sedangkan jumlah kasus baru BTA(+) yang ditemukan sebanyak 1.005 orang dan jumlah kasus lama TB Paru sebanyak 661 orang. Sedangkan menurut jenis kelamin, ditemukan sebanyak 1.017 kasus pada laki-laki dan 649 kasus pada perempuan. Dari jumlah tersebut maka prevalensi TB Paru tahun 2015 adalah sebesar 90,96 per 100.000 penduduk (Dinas Kesehatan Kota Tangerang. 2016).

Angka Kesembuhan (cure rate) TB Paru BTA (+) yaitu 88,02\%, sedangkan Angka Pengobatan Lengkap (complete rate) sebesar $2 \%$. Angka Keberhasilan Pengobatan (success rate) Tb Paru BTA (+) yaitu 90,02\%. 
Dari 1.005 penderita TB Paru BTA (+) tahun 2015 yang mendapatkan pengobatan, jumlah penderita yang dinyatakan sembuh berdasarkan hasil pemeriksaan dahaknya ( 2 kali negatif) berjumlah 926 orang atau $88,02 \%$ dari seluruh penderita. Jumlah penderita yang menjalani pengobatan lengkap dengan OAT selama 6 bulan sebanyak 21 orang atau $2 \%$ dari seluruh penderita, sehingga Angka Kesuksesan (Success Rate) pengobatan TB Paru adalah sebesar 90,02\%.

Menurut laporan tahunan Puskesmas Cipondoh Tangerang Banten tahun 2014 yang mengalami kasus TB Paru BTA Positif adalah 39 orang. Pada tahun 2015 jumlah kasus TB Paru BTA Positif adalah 25 orang. Kemudian pada tahun 2016 jumlah kasus TB Paru BTA Positif adalah 13 orang. Tetapi pada saat hari TB Nasional tahun 2017, petugas puskesmas Cipondoh Tangerang turun kelapangan untuk melakukan screening TB di wilayah kerja Puskesmas Cipondoh, dan didapat hasil sekitar 1000 orang tersuspect TB Paru. Akan tetapi yang melakukan follow up untuk memeriksakan kembali ke Puskesmas hanya 6 orang. Sehingga banyak suspect TB Paru di masyarakat yang tidak terdaftar dalam program di Puskesmas. Hal ini menunjukkan bahwa masih banyak masyarakat yang belum peduli terhadap kesehatan individu, diperlukan peran serta berbagai pihak seperti peran serta keluarga untuk mendukung anggota keluarga berobat ke fasilitas pelayanan kesehatan dan peran profesional kesehatan untuk melakukan komunikasi seperti penyuluhan-penyuluhan guna menanamkan kepatuhan masyarakat untuk berobat ke fasilitas pelayanan kesehatan.

Dari jumlah pasien TB Paru BTA Positif di Puseksmas Cipondoh Tangerang, semua pasien telah mendapatkan pengobatan dengan metode DOTS dan dari yang terdaftar di program DOTS tidak semua penderita patuh minum obat. Akibatnya pasien harus melakukan pengobatan ulang karena resistensi terhadap obat sehingga pengobatan akan membutuhkan waktu yang lebih lama. Oleh karena itu penulis tertarik untuk melakukan penelitian lebih lanjut tentang Faktor-Faktor yang Berhubungan terhadap Kepatuhan Pengobatan pada Penderita Tuberkulosis Paru BTA Positif di Puskesmas Cipondoh Tangerang Banten Tahun 2015-2016.

Hasil penelitian ini diharapan bermanfaat bagi Warga RW.005 Kelurahana Cibubur, pihak Puskesmas dan pihak Kelurahan Pemberantasan Sarang Nyamuk (PSN) 3M Plus Dengan Keberadaan Jentik Nyamuk Aedes aegypti Di Wilayah RW. 005 Kelurahan Cibubur,
Kecamatan Ciracas, Kota Jakarta Timur Tahun $2017 ”$

\section{METODE}

Penelitian ini dilakukan dengan dengan menggunakan desain "Case Control" yaitu untuk mengetahui faktor-faktor yang berpengaruh terhadap kepatuhan pengobatan penderita Tuberkulosis Paru BTA Positif Puskesmas Kecamatan Cipondoh, Tangerang, Banten Tahun 2015-2016. Penelitian Case Control merupakan suatu penelitian yang mempelajari faktor antara variabel independen (umur, jenis kelamin, tipe penderita tuberkulosis paru, lama pengobatan, jarak dari tempat tinggal ke puskesmas dan status PMO) dengan variabel dependen (kepatuhan pengobatan penderita Tuberkulosis Paru BTA Positif) dengan menggunakan data sekunder di Puskesmas Cipondoh Tangerang Banten.

Sampel adalah seluruh penderita TB Paru BTA Positif yang terdaftar di formulir TB01 di Puskesmas Cipondoh Tangerang Banten sesuai dengan karakteristik inklusi dan ekslusi.

\section{HASIL}

Tabel 1. Distribusi
$\begin{gathered}\text { Tuberkulosis } \\
\text { berdasarkan Kepatuhan }\end{gathered}$
\begin{tabular}{lrr} 
Paru & Pengobatan & Penderita \\
Kepatuhan Pengobatan & n & \% \\
\hline Patuh & 28 & 80,0 \\
Tidak Patuh & 7 & 20,0 \\
\hline Jumlah & 35 & 100 \\
\hline
\end{tabular}

Berdasarkan tabel 1 didapat hasil bahwa responden yang patuh dalam pengobatan Tuberkulosis paru BTA positif yaitu 28 orang dengan persentase $80 \%$. Sedangkan responden yang tidak patuh dalam pengobatan Tuberkulosis paru BTA positif yaitu 7 orang dengan persentase $20 \%$

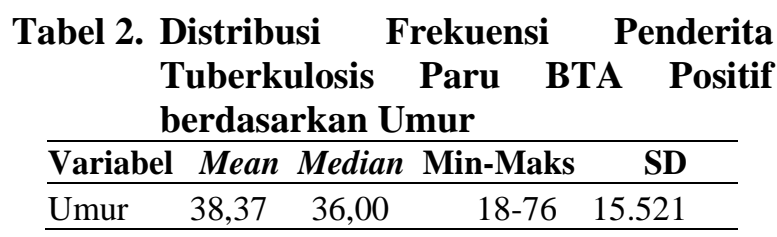

Berdasarkan tabel 2 didapat hasil bahwa rata-rata umur penderita yang berobat adalah 38,37 tahun, lalu median 36,00 tahun, minimal umur penderita yang berobat adalah 18 tahun 
sedangkan maksimal penderita yang berobat adalah 76 tahun. Standar deviasinya adalah 15,521 .

Tabel 3. Distribusi Frekuensi Penderita Tuberkulosis Paru BTA Positif berdasarkan Jenis Kelamin

\begin{tabular}{crr}
\hline Jenis Kelamin & \multicolumn{1}{c}{ Jumlah } & \multicolumn{1}{c}{$\%$} \\
\hline Laki-laki & 25 & 74,3 \\
Perempuan & 9 & 25,7 \\
\hline Total & $\mathbf{3 5}$ & $\mathbf{1 0 0 , 0}$ \\
\hline
\end{tabular}

Berdasarkan tabel 3 didapat hasil bahwa responden berjenis kelamin laki - laki yaitu 26 orang dengan persentase $74,3 \%$. Sedangkan responden yang berjenis kelamin perempuan yaitu 9 orang dengan persentase $25,7 \%$.

Tabel 4. Distribusi Frekuensi Penderita Tuberkulosis Paru BTA Positif berdasarkan Tipe Penderita

\begin{tabular}{lrr}
\hline \multicolumn{1}{r}{ Tipe Penderita } & Jumlah & \multicolumn{1}{c}{$\%$} \\
\hline Baru & 29 & 82,9 \\
Lama & 6 & 17,1 \\
\hline \multicolumn{1}{r}{ Total } & $\mathbf{3 5}$ & $\mathbf{1 0 0 , 0}$ \\
\hline
\end{tabular}

Berdasarkan tabel 4 didapat hasil bahwa responden yang memiliki tipe penderita baru yaitu 29 orang dengan persentase 82,9\%. Sedangkan responden yang memiliki tipe penderita lama yaitu 6 orang dengan persentase 17.

Tabel 5. Distribusi Frekuensi Penderita Tuberkulosis Paru BTA Positif berdasarkan Tipe Penderita

\begin{tabular}{crr}
\hline Lama Pengobatan & Jumlah & \multicolumn{1}{c}{$\%$} \\
\hline 6 Bulan & 29 & 82,9 \\
8 Bulan & 6 & 17,1 \\
\hline \multicolumn{1}{c}{ Total } & $\mathbf{3 5}$ & $\mathbf{1 0 0 , 0}$ \\
\hline
\end{tabular}

Berdasarkan tabel .5 didapat hasil bahwa responden yang memiliki lama pengobatan 6 bulan yaitu 29 orang dengan persentase $82,9 \%$. Sedangkan responden yang memiliki lama pengobatan 8 bulan yaitu 6 orang dengan persentase $17,1 \%$.

Tabel 6. Distribusi Frekuensi Penderita Tuberkulosis Paru BTA Positif berdasarkan Jarak dari Tempat Tinggal

\begin{tabular}{lcccc}
\hline Variabel & Mean & Med & Min-Maks & SD \\
\hline Jarak ke PKM & 1,5369 & 1,26 & $0,43-3,53$ & 0,91784 \\
\hline
\end{tabular}

Berdasarkan tabel 6 didapat hasil bahwa rata-rata jarak rumah penderita ke puskesmas adalah $1,5369 \mathrm{~km}$, lalu media $1,26 \mathrm{~km}$, minimal jarak rumah penderita ke puskesmas adalah $0,43 \mathrm{~km}$ sedangkan jarak maximal penderita kel puskesmas adalah $3,53 \mathrm{~km}$. Standar deviasi adalah 0,91784 .

Tabel 7. Distribusi Frekuensi Penderita Tuberkulosis Paru BTA Positif berdasarkan Status PMO

\begin{tabular}{lrr}
\hline Status PMO & Jumlah & \multicolumn{2}{c}{$\%$} \\
\hline Ada & 7 & 20,0 \\
Tidak Ada & 28 & 80,0 \\
\hline \multicolumn{1}{r}{ Total } & $\mathbf{3 5}$ & $\mathbf{1 0 0 , 0}$ \\
\hline
\end{tabular}

Berdasarkan tabel 7 didapat hasil bahwa responden yang memiliki PMO yaitu 7 orang dengan persentase $20 \%$. Sedangkan responden yang tidak memiliki PMO yaitu 28 orang dengan persentase $80 \%$.

Tabel 8. Hubungan Antara Umur dengan kepatuhan pengobatan penderita Tuberkulosis Paru BTA Paru Posisitf

\begin{tabular}{lrrrrrr}
\hline Umur & n & Mean & Med & SE & SD & p-value \\
\hline Patuh & 28 & 37,75 & 34,50 & 3,122 & 16,519 & \\
\cline { 1 - 5 } $\begin{array}{l}\text { Tidak } \\
\text { Patuh }\end{array}$ & 7 & 40,86 & 39,00 & 4.279 & 11,320 & 0,643 \\
\hline
\end{tabular}

Berdasarkan tabel 8 diketahui bahwa kelompok umur yang patuh yaitu 28 orang, rata-rata umur dengan kepatuhan berobat tuberkulosis paru BTA positif adalah 37,75 tahun dengan standar deviasi 16,519. Sedangkan kelompok umur yang tidak patuh yaitu 7 orang, rata-rata umur dengan ketidakpatuhan berobat tuberkulosis paru BTA positif adalah 40,86 tahun, dengan standar deviasi 11,320. $p$-value menunjukkan hasil uji statistik diperoleh nilai $p$-value $(0,643>\alpha 0,05)$, artinya tidak ada hubungan antara umur dengan kepatuhan pengobatan penderita Tuberkulosis Paru BTA Paru Posisitf di Puskesmas Cipondoh Tangerang Banten Tahun 2015-2016.

Tabel 9. Hubungan Antara Jenis Kelamin dengan kepatuhan pengobatan Penderita Tuberkulosis Paru BTA Paru Positif

\begin{tabular}{|c|c|c|c|c|c|c|}
\hline \multirow{3}{*}{ Jenis Kelamin } & \multicolumn{4}{|c|}{$\begin{array}{c}\text { Kepatuhan } \\
\text { Pengobatan }\end{array}$} & \multirow{2}{*}{\multicolumn{2}{|c|}{ Jlh }} \\
\hline & \multicolumn{2}{|c|}{ Patuh } & \multicolumn{2}{|c|}{$\begin{array}{l}\text { Tidak } \\
\text { Patuh }\end{array}$} & & \\
\hline & $\mathbf{n}$ & $\%$ & $\mathbf{n}$ & $\%$ & $\mathbf{n}$ & $\%$ \\
\hline Laki-Laki & 19 & 73,1 & 7 & 26,9 & 26 & 100 \\
\hline Perempuan & 9 & 100 & 0 & 0 & 9 & 100 \\
\hline Jumlah & 28 & 80 & 7 & 20 & 35 & 100 \\
\hline
\end{tabular}


Berdasarkan tabel 9 dapat diketahui hasil analisis hubungan antara jenis kelamin dengan kepatuhan pengobatan penderita tuberkulosis paru BTA positif diperoleh responden berjenis kelamin laki-laki yaitu 19 orang dengan persentase $73,1 \%$ yang patuh dalam pengobatan, dan 7 orang dengan persentase $26,9 \%$ yang tidak patuh dalam pengobatan. Sedangkan responden yang berjenis kelamin perempuan yaitu 9 orang dengan persentase $100 \%$ yang patuh dalam pengobatan, dan tidak ada yang tidak patuh dalam pengobatan.

Tabel 10. Hubungan Antara Tipe Penderita dengan Kepatuhan pengobatan Penderita Tuberkulosis Paru BTA Paru Posisitf

\begin{tabular}{|c|c|c|c|c|c|c|c|}
\hline \multirow{3}{*}{$\begin{array}{c}\text { Tipe } \\
\text { Penderita } \\
\text { TB Paru }\end{array}$} & \multicolumn{3}{|c|}{$\begin{array}{l}\text { Kepatuhan } \\
\text { Pengobatan }\end{array}$} & \multirow{2}{*}{\multicolumn{2}{|c|}{ Total }} & \multirow{3}{*}{$\begin{array}{r}\text { OR } \\
95 \% \\
-\quad \text { CI }\end{array}$} & \multirow{3}{*}{$\begin{array}{c}p \text { - } \\
\text { value }\end{array}$} \\
\hline & \multicolumn{2}{|c|}{ Patuh } & $\begin{array}{l}\text { Tidak } \\
\text { Patuh }\end{array}$ & & & & \\
\hline & $\mathbf{n}$ & $\%$ & n $\%$ & $\mathbf{n}$ & $\%$ & & \\
\hline Laki-Laki & 23 & 79,3 & 620,7 & 29 & 100 & 0,767 & \\
\hline Wanita & 5 & 83,3 & 116,7 & 6 & 100 & $\begin{array}{r}(0,075 \\
-7,86\end{array}$ & 1,000 \\
\hline Total & 28 & 80 & 20,3 & 35 & 100 & & \\
\hline
\end{tabular}

Berdasarkan tabel 10 dapat diketahui hasil analisis hubungan antara tipe penderita tuberkulosis paru dengan kepatuhan pengobatan penderita tuberkulosis paru BTA positif diperoleh responden yang memiliki tipe penderita baru yaitu 23 orang dengan persentase $79,3 \%$ yang patuh dalam pengobatan, dan 6 orang dengan persentase $20,7 \%$ yang tidak patuh dalam pengobatan. Sedangkan responden yang memiliki tipe penderita lama yaitu 5 orang dengan persentase $83,3 \%$ yang patuh dalam pengobatan, dan 1 orang dengan persentase $16,7 \%$ yang tidak patuh dalam pengobatan.

Uji statistik Fisher Exact diperoleh nilai $p$ value $=1,000$ atau nilai $p$-value $>0,05$. Maka dapat disimpulkan bahwa Ho diterima dan Ha ditolak, yaitu bahwa secara statistik tidak ada hubungan yang bermakna antara tipe penderita dengan kepatuhan pengobatan tuberkulosis paru BTA positif.
Tabel 11. Hubungan Antara Lama Pengobatan dengan Kepatuhan Pengobatan Penderita Tuberkulosis Paru BTA Paru Posisif

\begin{tabular}{|c|c|c|c|c|c|c|}
\hline \multirow{3}{*}{$\begin{array}{c}\text { Lama } \\
\text { Pengobat- } \\
\text { an }\end{array}$} & \multicolumn{2}{|c|}{$\begin{array}{c}\text { Kepatuhan } \\
\text { Pengobatan } \\
\end{array}$} & \multirow{2}{*}{\multicolumn{2}{|c|}{ Total }} & \multirow{3}{*}{\multicolumn{2}{|c|}{$\begin{array}{c}\text { OR } \\
95 \% \mathrm{CI}\end{array}$}} \\
\hline & Patuh & $\begin{array}{l}\text { Tidak } \\
\text { Patuh }\end{array}$ & & & & \\
\hline & $\%$ & n $\%$ & $\mathbf{n}$ & $\%$ & & \\
\hline 6 bulan & 2379,3 & 620,7 & 29 & 100 & 0,767 & \\
\hline 8 bulan & 583,3 & 116,7 & 6 & 100 & $\begin{array}{r}(0,075- \\
7,86\end{array}$ & - 1,000 \\
\hline Jumlah & 28 & $\begin{array}{ll}77 & 20\end{array}$ & 35 & 100 & & \\
\hline
\end{tabular}

Berdasarkan tabel 11 dapat diketahui hasil analisis hubungan antara lama pengobatan dengan kepatuhan pengobatan penderita tuberkulosis paru BTA positif diperoleh responden yang memiliki lama pengobatan 6 bulan yaitu 23 orang dengan persentase $79,3 \%$ yang patuh dalam pengobatan, dan 6 orang dengan persentase $20,7 \%$ yang tidak patuh dalam pengobatan. Sedangkan responden yang memiliki lama pengobatan 8 bulan yaitu 5 orang dengan persentase $83,3 \%$ yang patuh dalam pengobatan, dan 1 orang dengan persentase $16,7 \%$ yang tidak patuh dalam pengobatan.

Uji statistik Fisher Exact diperoleh nilai $p$ value $=1,000$ atau nilai $p$-value $>\alpha(0,05)$. Maka dapat disimpulkan bahwa Ho diterima dan $\mathrm{Ha}$ ditolak, yaitu bahwa secara statistik tidak ada hubungan yang bermakna antara lama pengobatan dengan kepatuhan pengobatan tuberkulosis paru BTA positif.

\section{Tabel 12. Hubungan antara Jarak dari Tempat Tinggal Pengobatan dengan Kepatuhan Pengobatan Penderita Tuberkulosis Paru BTA Paru Positif}

\begin{tabular}{lcccccc}
\hline $\begin{array}{l}\text { Jarak } \\
\text { rumah ke } \\
\text { PKM }\end{array}$ & n & Mean & Median & SD & SE & $\begin{array}{c}\boldsymbol{p} \text { - } \\
\text { value }\end{array}$ \\
\hline Patuh & 28 & 1,6536 & 1,2600 & 0,98277 & 1,8573 & 1,000 \\
$\begin{array}{l}\text { Tidak } \\
\text { Patuh }\end{array}$ & 7 & 1,0700 & 1,2600 & 0,33116 & 0,12517 & \\
\hline
\end{tabular}

Berdasarkan tabel 12 diketahui bahwa kelompok jarak rumah ke puskesmas yang patuh yaitu 28 orang, rata-rata jarak rumah ke puskesmas dengan kepatuhan berobat tuberkulosis paru BTA positif adalah 1,6536 km, dengan standar deviasi 0,98277. Sedangkan kelompok jarak rumah ke puskesmas yang tidak patuh yaitu 7 orang, rata-rata jarak rumah ke puskesmas dengan ketidakpatuhan berobat tuberkulosis paru BTA positif adalah 1,0700 km, dengan standar deviasi 0,33116 . Uji statistik 
Fisher Exact diperoleh nilai $p$-value $=1,000$ atau nilai $p$-value $>\alpha(0,05)$. Maka dapat disimpulkan bahwa yaitu bahwa secara statistik tidak ada hubungan yang bermakna antara jarak rumah ke Puskesmas dengan kepatuhan pengobatan tuberkulosis paru BTA positif.

\begin{tabular}{|c|c|c|c|}
\hline Tabe & $\begin{array}{l}\text { Hubungan } \\
\text { pengobatan } \\
\text { pengobatan }\end{array}$ & $\begin{array}{l}\text { status } \\
\text { dengan }\end{array}$ & $\begin{array}{r}\text { PMO } \\
\text { kepathan } \\
\text { Penderita }\end{array}$ \\
\hline & $\begin{array}{l}\text { Tuberkulosis } \\
\text { Positif }\end{array}$ & Paru & BTA Paru \\
\hline $\begin{array}{c}\text { Lama } \\
\text { Pengobat- }\end{array}$ & $\begin{array}{c}\text { Kepatuhan } \\
\text { Pengobatan } \\
\end{array}$ & Total & \\
\hline & $\begin{array}{ll}\text { Patuh } & \text { Tidak } \\
& \text { Patuh } \\
\end{array}$ & & $\begin{array}{c}\text { OR } \\
95 \% \text { CI value }\end{array}$ \\
\hline & $\begin{array}{llll}\text { n } & \% & \text { n } & \% \\
\end{array}$ & n $\%$ & \\
\hline Ada & $685,7 \quad 114,3$ & 7100 & $1,6361,000$ \\
\hline Tidak Ada & $2378,6 \quad 621,4$ & 28100 & $\begin{array}{r}(0,164- \\
16,345 \\
\end{array}$ \\
\hline & $\begin{array}{llll}28 & 80 & 7 & 20 \\
\end{array}$ & 35100 & \\
\hline
\end{tabular}

Berdasarkan tabel 13 dapat diketahui hasil analisis hubungan antara status PMO dengan kepatuhan pengobatan penderita tuberkulosis paru BTA positif diperoleh responden yang memiliki PMO yaitu 6 orang dengan persentase $85,7 \%$ yang patuh dalam pengobatan, dan 1 orang dengan persentase $14,3 \%$ yang tidak patuh dalam pengobatan. Sedangkan responden yang tidak memiliki PMO yaitu 22 orang dengan persentase $78,6 \%$ yang patuh dalam pengobatan, dan 6 orang dengan persentase $21,4 \%$ yang tidak patuh dalam pengobatan.

Uji statistik Fisher Exact diperoleh nilai $p$ value $=1,000$ atau nilai $p$-value $>\alpha(0,05)$. Maka dapat disimpulkan bahwa Ho diterima dan $\mathrm{Ha}$ ditolak, yaitu bahwa secara statistik tidak ada hubungan yang bermakna antara PMO dengan kepatuhan pengobatan tuberkulosis paru BTA positif.

\section{PEMBAHASAN}

\section{Kepatuhan Pengobatan Penderita Tuberkulosis Paru BTA}

Berdasarkan hasil yang telah didapat bahwa tingkat kepatuhan penderita tuberkulosis paru BTA positif dalam melaksanakan program pengobatan sudah berjalan dengan cukup baik, tetapi masih ada beberapa responden yang tidak mematuhi program pengobatan. Kepatuhan dipengaruhi oleh sikap penderita dalam mematuhi instruksi yang diberikan oleh profesional kesehatan, dalam hal ini petugas yang menangani tuberkulosis paru. Sikap ini merupakan respon yang diambil oleh penderita dari dorongan yang diterima, baik dari interaksi antara profesional kesehatan dengan pasien tentang pentingnya menjalankan pengobatan tuberkulosis paru sampai tuntas sehingga kesehatan akan pulih seperti sedia kala. Serta pemberikan informasi yang jelas dan gamblang pada pasien maupun keluarga yang ada tentang penyakit yang diderita dan cara pengobatannya.

Adapun ketidakpatuhan penderita tuberkulosis paru dikarenakan penderita tidak tepat waktu dalam meminum obat serta tidak tepat waktu dalam mengambil obat pada jadwal yang telah ditentukan oleh petugas kesehatan. selain itu kemungkinan disebabkan oleh padatnya aktivitas atau kesibukan sehari-hari sehingga penderita lupa minum obat serta rasa malas yang timbul akibat kejenuhan meminum obat dalam jangka waktu yang lama. Serta masih adanya anggota keluarga yang kurang peduli terhadap keluarganya sendiri, maka ada penderita mengambil obat sendiri tanpa didampingi oleh anggota keluarga. sehingga pada saat meminum obat penderita tidak patuh karena merasa tidak ada yang mengawasi atau mengingatkan tatkala timbul rasa malas ataupun lupa dalam meminum obat.

\section{Umur}

TB paru cenderung menular pada kelompok usia produktif, hal ini dapat di asumsikan karena pada usia tersebut orang mempunyai mobilitas yang sangat tinggi sehingga kemungkinan terpapar dengan kuman tuberkulosis paru lebih besar selain itu reaktifan endogen (aktif kembali yang telah ada dalam tubuh) terjadi pada usia yang sudah tua karena kondisi fisik yang sudah menurun sehingga sistem imun dalam tubuh tidak bisa melawan bakteri tuberkulosis paru yang menyerang tersebut.

\section{Jenis Kelamin}

Laki-laki cenderung lebih banyak merokok dimana merokok dapat berpengaruh terhadap kejadian tuberkulosis paru, selain itu karena lakilaki mencari nafkah diluar rumah sehingga banyak melakukan kontak dengan orang lain yang tidak diketahui apakah orang tersebut positif tuberkulosis paru atau tidak, sehingga apabila laki-laki tersebut berinterkasi kemudian orang tersebut batuk lalu droplet terhirup ke saluran pernafasan maka resiko untuk tertular 
lebih besar. Perempuan cenderung lebih waspada terhadap penyakit yang diderita karena takut menularkan kepada anaknya sehingga mereka akan berusaha untuk mencari pengobatan.

\section{Tipe Penderita Tuberkulosis Paru}

Berdasarkan hasil penelitian didapat hasil bahwa responden yang memiliki tipe penderita baru yaitu 29 orang dengan persentase $82,9 \%$. Sedangkan responden yang memiliki tipe penderita lama yaitu 6 orang dengan persentase 17,1\%. Hal ini disebabkan karena kebanyakan pasien yang berobat di Puskemas Cipondoh Tangerang termasuk kedalam pasien tipe penderita baru dibandingkan dengan pasien tipe lama (kambuh, berobat setelah putus berobat, gagal pada pengobatan sebelumnya).

\section{Lama Pengobatan}

Kebanyakan penderita tuberkulosis paru BTA positif yang berobat adalah tipe penderita baru dan termasuk ke dalam pengobatan kategori 1 yang memiliki jangka waktu pengobatan 6 bulan, sedangkan tipe penderita lama masuk dalam pengobatan kategori 2 yang memiliki jangka waktu pengobatan 8 bulan.

OAT (obat anti tuberkulosis) diberikan dalam bentuk kombinasi beberapa jenis obat sesuai dengan kategori pengobatan yang dijalani. Pengobatan tuberkulosis ini memiliki 2 tahap, yaitu tahap awal (intensif) selama 2 bulan dimana pasien wajib meminum obat setiap hari guna mengkonversi bakteri dari positif menjadi negatif. Selanjutnya tahap lanjutan selama 4 bulan, pasien diwajibkan mengambil dan meminum obat setiap hari senin, rabu dan jumat. Hal ini dilakukan untuk membunuh kuman persister sehingga pasien dapat sembuh dan mencegah terjadinya kekambuhan. Peran PMO sangat penting disini guna mengawasi penderita agar meminum obat sesuai dosis dan aturan yang telah ditetapkan.

\section{Jarak dari Tempat Tinggal ke Puskesmas}

Berdasarkan hasil penelitian didapat hasil bahwa rata-rata jarak rumah rumah penderita ke puskesmas adalah $1,5369 \mathrm{~km}$, lalu media 1,26 $\mathrm{km}$, minimal jarak rumah penderita ke puskesmas adalah $0,43 \mathrm{~km}$ sedangkan jarak maksimal penderita kel puskesmas adalah 3,53 km. Standar deviasi adalah 0,91784.

Berdasarkan persepsi sehat dan sakit, dikatakan bahwa setiap orang yang sakit akan mencari pengobatan ke tempat yang dianggap dapat memberikan pengobatan sehingga bisa mencapai kesembuhan atas sakit yang dideritanya.

\section{Status PMO dengan Kepatuhan Pengobatan Penderita Tuberkulosis Paru BTA Positif}

Berdasarkan hasil penelitian didapat hasil bahwa responden yang memiliki PMO yaitu 7 orang dengan persentase 20\%. Sedangkan responden yang tidak memiliki PMO yaitu 28 orang dengan persentase $80 \%$. Banyak pasien yang belum memiliki PMO (pengawas minum obat), padahal keberadaan PMO sangat dibutuhkan untuk mengawasi agar penderita tidak putus berobat atau berobat teratur.

\section{Hubungan Antara Umur Dengan Kepatuhan Pengobatan Penderita Tuberkulosis Paru BTA Positif}

Hal ini disebabkan oleh ada beberapa faktor lain yang lebih dominan mempengaruhi kepatuhan minum obat.

Adapun faktor-faktor yang mempengaruhi kepatuhan diantaranya pemahaman tentang instruksi yang jelas kepada pasien dan keluarga yang datang mengenai penyakit yang dideritanya serta cara pengobatannya sehingga pasien umur dewasa muda maupun umur dewasa tua mampu untuk melaksanakan pengobatan dengan benar dan teratur sesuai instruksi petugas kesehatan. Tingkat pendidikan serta pengetahuan juga mempunyai peran yang penting pula karena dengan adanya pengetahuan penderita memahami instruksi yang diberikan petugas kesehatan sehingga tidak akan terjadi kesalahfahaman dalam memahami instruksi yang diberikan, sikap yang positif juga sangat dibutuhkan dalam menjalani pengobatan sehingga penderita dapat menanamkan keyakinan bahwa kesehatan mereka akan pulih seperti sedia kala maka mereka mampu menjalani pengobatan hingga tuntas dan sembuh, dukungan keluarga merupakan hal yang penting karena dengan adanya dukungan tersebut pasien berumur dewasa muda maupun dewasa tua akan merasa diperdulikan seperti pada saat berobat penderita didampingi oleh anggota keluarganya sehingga dorongan-dorongan yang diberikan kepada penderita supaya patuh berobat akan dilaksanakan dengan baik.

\section{Hubungan Antara Jenis Kelamin Dengan Kepatuhan Pengobatan Penderita Tuberkulosis Paru BTA Positif}

Hal ini disebabkan karena penderita tuberkulosis paru BTA positif baik yang berjenis 
kelamin laki-laki maupun perempuan memiliki risiko yang sama untuk patuh atau tidak patuh didalam pengobatan dan juga kemauan untuk sembuh dari penyakitnya sehingga bisa sehat seperti sedia kala mendorong setiap individu untuk melakukan pengobatan tidak peduli lakilaki maupun perempuan. Sesuai dengan penelitian ini menyatakan bahwa tingginya angka penderita laki-laki disebabkan oleh kebiasaan merokok tembakau dan minum alkohol yang dapat menurunkan sistem pertahanan tubuh sehingga lebih rentan terpapar dengan agent penyebab tuberkulosis paru. Hal ini bisa diatasi dengan meningkatkan intensitas dan kualitas penyuluhan sehingga penderita sadar akan pentingnya menjaga pola hidup yang sehat dan pengobatan tuberkulosis paru secara teratur hingga tuntas, karena apabila tidak tuntas maka akan memperberat pengobatan dan bisa menjadi agen penyebar penyakit tuberkulosis, baik dilingkungan rumah maupun dilingkungan penderita bekerja.

Hal ini sejalan dengan penelitian yang dilakukan oleh Dewi (2011) di Puskesmas Lidah Kulon Surabaya yang menyatakan bahwa tidak ada hubungan antara variabel jenis kelamin dengan tingkat kepatuhan pengobatan tuberkulsosis paru.

\section{Hubungan Antara Tipe Penderita dengan Kepatuhan Pengobatan Penderita Tuberkulosis Paru BTA Positif}

Uji statistik Fisher Exact diperoleh nilai $p$ value $=1,000$ atau nilai $p$-value $>\alpha(0,05)$. Maka dapat disimpulkan bahwa Ho diterima dan $\mathrm{Ha}$ ditolak, yaitu bahwa secara statistik tidak ada hubungan yang bermakna antara tipe penderita dengan kepatuhan pengobatan tuberkulosis paru BTA positif.

Penderita tuberkulosis paru BTA positif yang memiliki tipe baru maupun lama tidak menjamin mereka patuh ataupun tidak patuh dalam pengobatan karena itu tergantung dari kesadaran serta kemauan masing-masing individu untuk sembuh maupun tidak sembuh dalam pengobatan. Jika penderita ingin sembuh maka harus mematuhi instruksi yang diberikan petugas kesehatan untuk patuh dalam pengobatan tuberkulosis paru ini. Oleh karena itu peran serta PMO sangat penting guna membantu penderita untuk mengingatkan minum obat anti tuberkulosis setiap harinya.

\section{Hubungan Antara Jarak Dari Tempat Tinggal Ke Puskesmas Dengan Kepatuhan Pengobatan Penderita Tuberkulosis Paru BTA Positif}

Sarana dan prasarana transportasi di wilayah Cipondoh Tangerang menuju Puskesmas telah tersedia dari berbagai arah sehingga pasien yang ingin menuju ke Puskesmas Cipondoh untuk berobat dapat menggunakan saran transpotasi yang ada tanpa kendala. Hal ini sejalan dengan penelitian yang dilakukan oleh Maesaroh (2009) di Klinik Jakarta Respiratory Centre (JCR)/PPTI yang menyatakan bahwa tidak ada hubungan yang bermakna antara jarak klinik dari tempat tinggal responden dengan kepatuhan berobat pasien tuberkulosis paru BTA positif.

Dalam penelitian Chomisah (2001) menunjukkan $p=0,876$ dengan $\alpha=5 \%$ tidak ada perbedaan persentase kepatuhan berobat penderita tuberkulosis paru antara responden yang berjarak dekat dengan responden yang berjarak jauh.

Notoatmodjo (2010) menjelaskan tentang persepsi sehat dan sakit, dimana dikatakan bahwa setiap orang yang sakit akan mencari pengobatan ke tempat yang dianggap dapat memberikan pengobatan sehingga bisa mencapai kesembuhan atas sakit yang dideritanya, perilaku ini hampir dilakukan oleh setiap individu. Dapat disimpulkan bahwa jarak bukanlah suatu penghalang bagi penderita untuk patuh maupun tidak patuh dalam pengobatan, karena kepatuhan itu sendiri didorong oleh kemauan diri sendiri agar sembuh dan sehat seperti sedia kala.

\section{Hubungan Antara status PMO Dengan Kepatuhan Pengobatan Penderita Tuberkulosis Paru BTA Positif}

Uji statistik Fisher Exact diperoleh nilai $p$ value $=1,000$ atau nilai $p$-value $>\alpha(0,05)$. Maka dapat disimpulkan bahwa Ho diterima dan $\mathrm{Ha}$ ditolak, yaitu bahwa secara statistik tidak ada hubungan yang signifikan antara status PMO dengan kepatuhan pengobatan tuberkulosis paru BTA positif.

Tugas seorang PMO ialah untuk mengingatkan penderita dalam mengambil obat, mengawasi menelan obat. Adanya dukungan atau motivasi yang penuh dari keluarga dapat mempengaruhi perilaku meminum obat pasien tuberkulosis paru secara patuh. Sehingga keluarga perlu berperan aktif mendukung supaya pasien menjalani pengobatan secara teratur sampai dinyatakan sembuh oleh petugas 
kesehatan. tetapi masih ada anggota yang menghindari pasien yang menyebabkan pasien merasa malu untuk menjalani pengobatan.

Selain faktor eksternal, faktor internal pun sangat berpengaruh terhadap kepatuhan berobat pasien, salah satunya ialah sikap dan kepribadian. Penderita yang mempunyai sikap positif maka akan patuh menjalankan pengobatan sesuai dengan instruksi yang diberikan baik itu dengan adanya seorang PMO maupun tidak adanya PMO.

\section{SIMPULAN}

1. Gambaran kepatuhan pengobatan tuberkulosis paru BTA positif sebagian besar responden patuh dalam pengobatan Tuberkulosis paru BTA positif yaitu 28 responden $(80 \%)$.

2. Berdasarkan variabel golongan umur diketahui mean adalah 38,37 tahun, lalu median 36,00 tahun, minimal adalah 18 tahun sedangkan maximal adalah 76 tahun. Standar deviasinya adalah 15,521.

3. Berdasarkan variabel jenis kelamin sebagian besar responden berjenis kelamin laki - laki yaitu 26 orang $(74,3 \%)$.

4. Berdasarkan variabel tipe penderita sebagian besar responden memiliki tipe baru yaitu 29 orang $(82,9 \%)$.

5. Berdasarkan variabel lama pengobatan sebagian besar responden memiliki lama pengobatan 6 bulan yaitu 29 orang $(82,9 \%)$.

6. Berdasarkan variabel jarak dari rumah ke puskesmas diketahui mean adalah 1,5369 $\mathrm{km}$, lalu media $1,26 \mathrm{~km}$, minimal adalah $0,43 \mathrm{~km}$ sedangkan maximal adalah 3,53 $\mathrm{km}$. Standar deviasi adalah 0,91784.

7. Berdasarkan variabel status PMO sebagian besar responden tidak memiliki PMO yaitu 28 orang $(80 \%)$.

8. Hubungan antara jenis kelamin dengan kepatuhan pengobatan tuberkulosis paru BTA positif menunjukkan nilai $p$ value $=0,153$ atau nilai $p$-value $>\alpha(0,05)$. Tetapi hasilnya tidak bisa dibaca karena ada cell yang nilainya 0 .

9. Hubungan antara umur dengan kepatuhan berobat tidak bisa diketahui karena data tidak sesuai persyaratan sehingga tidak bisa diolah.

10. Hubungan antara tipe penderita dengan kepatuhan pengobatan tuberkulosis paru BTA positif menunjukkan tidak ada hubungan yang signifikan, hal ini ditunjukkan dengan nilai $p$-value $=1,000$ atau nilai $p$-value $>\alpha(0,05)$.

11. Hubungan antara lama pengobatan dengan kepatuhan pengobatan tuberkulosis paru BTA positif menunjukkan tidak ada hubungan yang signifikan, hal ini ditunjukkan dengan nilai $p$-value $=1,000$ atau nilai $p$-value $>\alpha(0,05)$.

12. Hubungan antara faktor jarak rumah ke puskesmas dengan kepatuhan berobat menunjukkan tidak ada hubungan yang signifikan, hal ini ditunjukkan dengan nilai $p$-value $=1,000$ atau nilai $p$-value $>\alpha(0,05)$.

13. Hubungan antara faktor status PMO dengan kepatuhan pengobatan penderita tuberkulosis paru BTA positif. Hubungan antara status PMO dengan kepatuhan pengobatan penderita tuberkulosis paru BTA positif menunjukkan tidak ada hubungan yang signifikan, hal ini ditunjukkan dengan nilai $p$-value $=1,000$ atau nilai $p$-value $>\alpha \underset{c}{\alpha}(0,05)$.

\section{SARAN}

1. Tingkatkan kualitas penyuluhan menggunakan materi TB dengan singkat dan jelas lalu tingkatkan kuantitas penyuluhan agar penderita

yang belum patuh dalam pengobatan mau untuk

patuh dengan menambah waktu penyuluhan sebulan 2 kali.

2. Ajak anggota keluarga penderita pada saat penyuluhan agar dapat membantu mengawasi penderita dalam mengambil dan meminum obat.

3. Perlu dilakukan penelitian lanjutan mengenai faktor lain yang berhubungan dengan kepatuhan pengobatan tuberkulosis paru seperti variabel pengetahuan, tingkat pendidikan, sikap, efek samping obat, serta dukungan keluarga.

\section{DAFTAR PUSTAKA}

Dewi, P. M. S. 2011. Hubungan Pengetahuan dan Sikap Penderita TB Paru dengan Kepatuhan Minum Obat Anti Tuberkulosis

di Puskesmas Lidah Kulon Surabaya. [ Disertasi]. Surabaya: Universitas Airlangga. 
Dinas Kesehatan Kota Tangerang. 2016. Profil Kesehatan Kota Tangerang Banten 2015. Tangerang, Banten.

Kemenkes RI. 2011. Strategi Nasional Pengendalian TB di Indonesia 2010 2014. Jakarta: Direktorat Jendral Pengendalian Penyakit dan Penyehatan Lingkungan.

Kemenkes RI. 2013. Riset Kesehatan Dasar 2013. Jakarta: Litbangkes RI.

Kemenkes RI. 2014. Pedoman Nasional Pengendalian TB. Jakarta: Direktorat Pengendalian Penyakit dan Penyehatan Lingkungan.

Kemenkes RI. 2015. Profil Kesehatan 2014. Jakarta: Kementrian Kesehatan.

Maesaroh, S. 2009. Faktor-Faktor yang Berhubungan dengan Kepatuhan Berobat Pasien Tuberkulosis Paru di Klinik Jakarta
Respiratory Centre (JRC)/PPTI Tahun 2009. [Skripsi]. Jakarta: Universitas Islam Negeri Jakarta.

Notoadmodjo, Soekidjo. 2010. Kesehatan Masyarakat Ilmu dan Seni. Jakarta: Rineka Cipta.

Prayogo, A. H. E. 2013. Faktorfaktor yang mempengaruhi kepatuhan minum obat anti Tuberkulosis pada pasien Tuberkulosis Paru di Puskemas Pamulang Tangerang Selatan Provinsi Banten periode Januari 2012-Januari 2013. [Laporan Penelitian]. Jakarta: Fakultas Kedokteran dan Ilmu Kesehatan, Universitas Islam Negeri Sjarif Hidayatullah.

World Health Organization. 2016. Global tuberculosis report 2016. WHO Library Cataloguing-in-Publication Data. 